\title{
Human Capital and the Level of Economic Development
}

\author{
Rewat Thamma-Apiroam ${ }^{1}$ \\ ${ }^{1}$ Department of Economics, Faculty of Economics, Kasetsart University, Bangkok, Thailand \\ Correspondence: Rewat Thamma-Apiroam. Tel: 66-2579-8739. E-mail: fecoret@hotmail.com \\ Received: October 19, 2017 \\ Accepted: October 27, $2017 \quad$ Online Published: January 29, 2018 \\ doi:10.5539/ass.v14n2p31 \\ URL: https://doi.org/10.5539/ass.v14n2p31
}

\begin{abstract}
This study aims at testing the causal relationship between human capital via the government spending share on education and economic growth using cross-country evidence and investigating the relationship pattern between such human capital - growth and the level of economic development based on 30 country data. The study employs a standard approach through uniting root test and Granger causality test. The data is annually collected during the periods $1983-2012$, totaling to 30 observations. The finding indicates that for both developing and developed countries, education human capital cannot explain much the economic growth and vice versa. In addition, from the relationship pattern between human capital - growth and the economic development level neutrality is the most commonly found pattern for both developing and developed countries. However, we see somewhat difference between them in terms of causation running from growth to human capital. That is, the number of developed countries is almost double as compared to the developing ones. This gives rise to a policy implication for developed countries in that it should put more emphasis on the government education spending share to GDP since it can help boost human capital in the long run.
\end{abstract}

Keywords: economic growth, government spending on education, Granger causality test, human capital

\section{Introduction}

Human capability has long been known as indispensable to economic growth. Not only does human capital is a crucial factor of production, but it can lead to positive externalities as well. Human capital might be accumulated through education, training, health care, and labor migration, for example. In the case of education, the educational expenses can be compared to the value of machines since both are investment costs. Therefore, human capital is essential to the economy in that respect. The role of human capabilities on economic growth has been studied by scholars for years. Schultz (1961) invented the term "human capital" and referred it to the value of human capabilities. He mentioned that human capital is comparable to other types of capital because it could be invested in various ways such as education, training, and health. For instance, if one has more education and training or better health, he or she would have more accumulated personal human capital stock. Consequently, such investment will cause their productivity higher, thus raising one's earnings and higher aggregate level of production. This will also boost the national income. As such, it is a starting point for researchers to seriously investigate roles and importance of human capital on the economy. Becker (1964), Arrow (1962), Mincer (1962), and Romer (1986) among other scholars examined its impact on one's well-being and economy in various analytical frameworks. This challenges scholars to find a way to match concepts with empirical evidence.

In the past, conventional wisdom on economic growth and economic development stresses the significance of human capital. Does education human capital stimulate income? The answer can be separated into two cases. The first is to consider it at individual level. Apparently, the answer is well established since micro economic studies find quite robust labor market returns to education. However, the latter at macro economic level is found to be inconclusive. Such the finding is due to at least three factors. Firstly, it is difficult to quantitatively measure human capital since it is intrinsically a qualitative variable. Scholars have attempted to measure it through average years of education but focusing on the average is likely to yield a mixed impact of various levels of education attainment. Consequently, this cannot clearly answer what level of human capital drives growth most? Secondly, suppose the correlation between human capital and economic development does exist, but this does not mean human capital would lead to economic development. This is because there are numerous factors that influence or co-vary with human capital such as various institutional and cultural differences between countries. Lastly, such the correlation might be spurious. For instance, the higher income and faster growth rates can bring about even more resources to invest in education. That is, using the correlation between the current levels of human capital and income proxies may encounter the "reverse causality" problem. In other words, human capital 
is merely accumulated owing to income.

Another way to gain a deeper understanding about human capital is through investigating causal relationships between human capital and economic growth. The point of investigating causations of human capital and growth lies in that such causal patterns might be correlated with the level of GDP and economic growth. More specifically, if the government expenditures on education are used as proxy for human capital, then does human capital cause growth or vice versa? How about the causation in countries with different levels of growth and development? Knowing the answer and being able to identify the pattern is paramount to the human capital and growth policies. There are a large number of existing literatures studying the relationship between education human capital and economic growth but they do not directly relate it to the level of economic development. Therefore, this present paper is an attempt to search for that relationship.

Jacob Mincer (1981) studied the relationship between human capital and economic growth. He asserted that human capabilities can be formed through formal and informal schooling at school and at home, and through training, experience, and labor mobility both domestically and internationally. If the accumulation of personal human capital increases, so does the national income. At the aggregate level, human capital is deemed to be an important factor of production along with physical capital. This means that its contribution to economic growth would be higher if more of physical capital has been used. According to his study, human capital is the cause of growth and a consequence of the growth as well. That is, there exists a bidirectional relationship between human capital and economic growth. He also emphasized that human capital is not only the transmission and embodiment in people of available knowledge, but the production of new knowledge which in turn is the cause of innovation and technological progress as well. In conclusion, human capital is considered both a necessity and a consequence of economic growth. Also, Erich Gundlach (1996) examined the role of human capital in macroeconomic environment. He asserted that studies on the relationship between human capital and microeconomic variables can be ubiquitously found. However, there are little studies on the relationship between human capital and economic development. He extended the Solow growth model by adding a human capital variable into his own model. Furthermore, he calculated the elasticity of human capital which is equivalent to share of human capital to the total income. Three types of empirical macroeconomic studies have been selected in order to investigate the role of human capital in economic development. One is that the growth rate of output per person is regressed on output person and a number of other repressors, including human capital variable. The second is that output per person is regressed on the stocks of physical and human capital and the last specification is that output per person is regressed on the rate of population growth as well as on the investment rates of physical and human capital variables. The result on production elasticities of human capital and physical capital is that they are in the range of $60 \%$ and $25 \%$, respectively. As such, he stressed that the econometric results do not provide a clear cut assessment of the role of human capital in economic development at the aggregate level. The next two papers are to examine the relationship between education government expenditures and economic growth in developing countries. Chandra Abhijeet (2010) investigated causal relationship between education expenditures and economic growth of India during the period 1951-2009. He used a time-series econometric analysis through linear and nonlinear Granger Causality method. His findings indicated that economic growth of India does affect the level of government expenditures on education for every time lag. However, education government expenditures only affect economic growth after some time lags. He also mentioned that using a linear Granger Causality is imperative to identifying the predictive ability of the time -series models. Nonetheless, he argued that by nature the direction of causality between education spending and economic growth might be more complex. Therefore, investigating such the relationship between education government spending and growth through nonlinear Granger Causality is worthwhile. Douanla Tayo Lionel and Aboma Fouda Marcel (2015) studies and assessed the effect of education government spending on economic growth of Cameroon over the period 1980-2012 through a standard vector error correction model. They applied the standard model of Cobb-Douglas production function but added a human capital variable proxied by the government expenditure on education. The standard procedure such as unit root test, lag length test, co-integration test, and vector error correction has been performed. Their results showed that education government expenditure has a significant and positive effect on economic growth of Cameroon both in the short run and long run. The estimated error correction model indicated that every $1 \%$ increase in education government spending and physical capital resulted in approximately $10 \%$ and $5 \%$ increase, respectively on economic growth in the long run. They, therefore, concluded that education spending is a crucial engine of the economic growth in Cameroon.

According to the existing literature, it is still controversial whether government spending on education causes economic growth, or growth causes higher government spending on education, or they have bidirectional 
causality. However, it is not known that the level of economic development might be a contributing factor in determining the relationship between government spending on education and economic growth.

Thus, the main purposes of this study are to empirically test the causative directions between education human capital and economic growth and to establish the relationship pattern between education human capital and the level of economic development using cross-country evidence. One of the benefits is that we are able to compare the results and probably detect the patterns of causality when different levels of economic development are taken into consideration.

The organization of this research is straightforward. Scope of the study and methodology are expressed in the next section. This section explains the sources of data, periods of data observed, and description of the data including the methodologies utilized to respond to the objectives of the study. This includes econometric models and how to estimate as well as how the results would be interpreted. Next is the result and discussion section. The last section is conclusion.

\section{Scope and Method}

This study employs annual time-series data for the period $1983-2012$, totaling to 30 observations. The data employed is the cross-country data for 30 countries separated by the level of economic development developing countries and developed countries. And government expenditures on education are used as the proxy for education human capital and the percentage increase in gross domestic products is used as economic growth since the research topic concerns aggregate macroeconomic data. Moreover, the model used in this study is an application of human capital-based endogenous growth theory but the main point is neither to establish the relation between factors of production and the aggregate output as in the setting of growth model, nor to find the steady state solutions. Instead, it is to find the relation patterns between education human capital to growth and the level of economic development using cross-country evidence. Such the pattern is derived from the causality test of each country.

Sources of data are as follows. The GDP and GDP growth rate is from the United Nations (www.data.un.org) and the percentage of government expenditures on education are also obtained from the United Nations. More specifically, it is from UNESCO Institute for Statistics - Educational, Scientific and Cultural Organization. In addition, the list of developing and developed countries is from the United Nations (United Nations, 2013). The List of countries used in this study is as follows.

Developing Countries: Argentina, Bangladesh, Cameroon, China, Costa Rica, Ethiopia, Gambia, Iran, Jamaica, Kenya, Mauritius, South Africa, Swaziland, Thailand and Tunisia

Developed Countries: Austria, Canada, Denmark, Finland, France, Ireland, Japan, Korea, Netherlands, New Zealand, Norway, Portugal, Switzerland, United Kingdom and United States of America

The methods corresponding to the each objective are described separately.

1) Causal relationships between education human capital and economic growth

The methodology for the first objective is quantitative. This part is in essence a time-series macroeconomic analysis. The growth rate of gross domestic products as indicative of economic growth and the percentage of government spending on education to GDP as proxy for human capital are variables of interest. Based on unit root test, all data are examined by Augmented Dickey Fuller test to see whether non-stationary problem is present. If variables are stationary, then we proceed to the next step; otherwise, data differencing with appropriate lag number is needed to be certain that the estimation does not lead to spurious results. The variables are tested for causative directions, namely unidirectional causation, bidirectional causation, and neutrality using pairwise Granger causality test.

\section{The Econometric Model}

According to a framework of endogenous growth model, the production function takes the Cobb-Douglas form as the following.

$$
\ln Y(t)=\ln A+\alpha \ln K(t)+\beta \ln L(t)+\gamma \ln H(t)+\varepsilon(t),
$$

where $\mathrm{Y}$ is GDP or output, $\mathrm{K}$ is the capital stock, $\mathrm{L}$ is labor, $\mathrm{H}$ is human capital, $\ln$ is natural $\log , \varepsilon$ is disturbance term, $\alpha, \beta, \gamma$, and $\ln A$, are coefficients, and $t$ is time. The coefficient in front of each variable is the elasticity of output with respect to that specific input. Such interpretation explicitly makes human capital an endogenous determinant of growth since if the stock of human capital increases by one percent, how much of the GDP will rise, which is the growth rate per se. Nevertheless, the objective of this section is to find the casual relationship patterns between human capital and economic growth, a linear relationship is assumed. Furthermore, according 
to the new or endogenous growth, the dependent and independent variables are as the following.

$$
y g(t)=\alpha+\beta H C(t)+\zeta(t),
$$

where $y g$ is the growth rate of GDP.

$H C$ is the share of spending on education to GDP as proxy for human capital.

$\zeta$ is the disturbance term.

$\alpha$ and $\beta$ are parameters to be estimated.

$\mathrm{t}$ is time.

After the linear relationship is by assumption established, then the standard procedures typically used in time-series analysis are performed as mentioned earlier.

Note that if the unit root problem (based on the Augmented Dickey Fuller test) is not present (or after differencing), the causality test can be used to determine the causal relation patterns. To test for causality between education human capital and economic growth, we use an econometric technique that can verify such causations, typically the Granger causality test.

2) Investigation of the relationship pattern between education human capital - growth and economic development level

The methodology for the second objective is qualitative. The data of this part is based on the previous results. After performing the causality test, separately for each country classified by developing and developed countries, we attempt to investigate the relationship pattern to see if there exist the different causation directions between the developing and the developed. Descriptive statistics such as frequency and graph are used in explaining the result to this objective.

\section{Results and Discussion}

This section provides the results of the study in response to all the objectives. Firstly, to investigate the causal relationships, if there exist, between education human capital and economic growth for both developing and developed countries by using the share spent on education to GDP as proxy for human capital. The results are the following, respectively.

\subsection{Estimation Results}

This present study uses time-series econometric models pertaining to unit root test and Granger causality test. Key macroeconomic variables of countries employed in this study are GDP growth and share of government's expenditures on education to GDP as proxy for human capital. The data used in this study is aggregate annual time series during the period of 1983-2012. First we check the stability of the data. The statistical methods utilized are the unit root test and the Granger causality test. Before applying the Granger causality, a standard test as unit root was performed. The yg is the growth rate of GDP and HC is the share of government's expenditures on education to GDP. The unit root test results are shown in table 1 and table 2.

Table 1. Unit Root Test for Developing Countries

\begin{tabular}{|c|c|c|c|c|c|c|c|}
\hline & \multicolumn{7}{|c|}{ Variable in } \\
\hline & & \multicolumn{3}{|c|}{ Level } & \multicolumn{3}{|c|}{ First Diff. } \\
\hline & & ADF Value & Decision & Sig. & ADF Value & Decision & Sig. \\
\hline \multicolumn{8}{|c|}{ Argentina } \\
\hline & $\ln (\mathrm{yg})$ & -1.754543 & No Unit Root & 0.10 & -3.908210 & No Unit Root & 0.01 \\
\hline & $\ln (\mathrm{HC})$ & -0.866267 & Unit Root & $\mathrm{N} / \mathrm{A}$ & -4.649104 & No Unit Root & 0.01 \\
\hline \multicolumn{8}{|c|}{ Bangladesh } \\
\hline & $\ln (\mathrm{yg})$ & -4.206757 & No Unit Root & 0.05 & -6.022089 & No Unit Root & 0.01 \\
\hline & $\ln (\mathrm{HC})$ & -2.482203 & Unit Root & N/A & -3.343180 & No Unit Root & 0.05 \\
\hline \multicolumn{8}{|c|}{ Cameroon } \\
\hline & $\ln (y g)$ & -1.721417 & Unit Root & N/A & -3.723479 & No Unit Root & 0.05 \\
\hline & $\ln (\mathrm{HC})$ & -2.045414 & Unit Root & N/A & -3.562350 & No Unit Root & 0.05 \\
\hline \multicolumn{8}{|c|}{ China } \\
\hline & $\ln (\mathrm{yg})$ & -4.523782 & No Unit Root & 0.01 & -6.227533 & No Unit Root & 0.01 \\
\hline & $\ln (\mathrm{HC})$ & -1.203447 & Unit Root & N/A & -4.115981 & No Unit Root & 0.01 \\
\hline \multicolumn{8}{|c|}{ 5. Costa Rica } \\
\hline & $\ln (\mathrm{yg})$ & -4.273872 & No Unit Root & 0.01 & -5.148734 & No Unit Root & 0.01 \\
\hline & $\ln (\mathrm{HC})$ & -2.740875 & Unit Root & N/A & -3.593081 & No Unit Root & 0.05 \\
\hline
\end{tabular}




\begin{tabular}{|c|c|c|c|c|c|c|c|}
\hline \multicolumn{8}{|c|}{ 6. Ethiopia } \\
\hline & $\ln (y g)$ & -3.657189 & No Unit Root & 0.10 & -6.082653 & No Unit Root & 0.01 \\
\hline & $\ln (\mathrm{HC})$ & -2.408979 & Unit Root & N/A & -3.858017 & No Unit Root & 0.05 \\
\hline \multicolumn{8}{|c|}{ Gambia } \\
\hline & $\ln (y g)$ & -2.033877 & Unit Root & N/A & -3.302050 & No Unit Root & 0.05 \\
\hline & $\ln (\mathrm{HC})$ & -1.614200 & Unit Root & N/A & -3.689248 & No Unit Root & 0.05 \\
\hline \multicolumn{8}{|c|}{ Iran } \\
\hline & $\ln (y g)$ & -3.244292 & No Unit Root & 0.05 & -5.273383 & No Unit Root & 0.01 \\
\hline & $\ln (\mathrm{HC})$ & -1.918534 & Unit Root & $\mathrm{N} / \mathrm{A}$ & -4.278055 & No Unit Root & 0.01 \\
\hline \multicolumn{8}{|c|}{ Jamaica } \\
\hline & $\ln (y g)$ & -3.108310 & Unit Root & N/A & -3.240918 & No Unit Root & 0.05 \\
\hline & $\ln (\mathrm{HC})$ & -2.856052 & Unit Root & N/A & -4.730448 & No Unit Root & 0.01 \\
\hline \multicolumn{8}{|c|}{ Kenya } \\
\hline & $\ln (\mathrm{yg})$ & -3.506362 & No Unit Root & 0.05 & -5.421356 & No Unit Root & 0.01 \\
\hline & $\ln (\mathrm{HC})$ & -3.624820 & No Unit Root & 0.05 & -3.289850 & No Unit Root & 0.05 \\
\hline \multicolumn{8}{|c|}{ Mauritius } \\
\hline & $\ln (y g)$ & -3.848781 & No Unit Root & 0.01 & -6.383855 & No Unit Root & 0.01 \\
\hline & $\ln (\mathrm{HC})$ & -3.045572 & No Unit Root & 0.05 & -4.817244 & No Unit Root & 0.01 \\
\hline \multicolumn{8}{|c|}{ South Africa } \\
\hline & $\ln (y g)$ & -2.502036 & Unit Root & N/A & -3.789067 & No Unit Root & 0.05 \\
\hline & $\ln (\mathrm{HC})$ & -1.808296 & Unit Root & N/A & -3.136529 & No Unit Root & 0.05 \\
\hline \multicolumn{8}{|c|}{ Swaziland } \\
\hline & $\ln (y g)$ & -3.024548 & Unit Root & N/A & -4.837577 & No Unit Root & 0.01 \\
\hline & $\ln (\mathrm{HC})$ & -1.100868 & Unit Root & N/A & -3.961980 & No Unit Root & 0.05 \\
\hline \multicolumn{8}{|c|}{ Thailand } \\
\hline & $\ln (y g)$ & -2.315371 & Unit Root & $\mathrm{N} / \mathrm{A}$ & -2.836018 & No Unit Root & 010 \\
\hline & $\ln (\mathrm{HC})$ & -2.196274 & Unit Root & $\mathrm{N} / \mathrm{A}$ & -3.505748 & No Unit Root & 0.10 \\
\hline \multicolumn{8}{|c|}{ Tunisia } \\
\hline & $\ln (y g)$ & -6.880373 & No Unit Root & 0.01 & -5.423538 & No Unit Root & 0.01 \\
\hline & $\ln (\mathrm{HC})$ & -2.375166 & Unit Root & $\mathrm{N} / \mathrm{A}$ & -5.167146 & No Unit Root & 0.01 \\
\hline
\end{tabular}

Note: N/A Not Applicable

According to table 1, for Argentina, the ADF value for the first difference in $\ln (\mathrm{yg})$ is -3.908210 and the ADF value for the first difference in $\ln (\mathrm{HC})$ is -4.649104 , so that both series do not have a unit root problem at first differencing.

For Bangladesh, the ADF value for the first difference in $\ln (\mathrm{yg})$ is -6.022089 and the ADF value for the first difference in $\ln (\mathrm{HC})$ is -3.343180 , so that both series do not have a unit root problem at first differencing.

For Cameroon, the ADF value for the first difference in $\ln (\mathrm{yg})$ is -3.723479 and the ADF value for the first difference in $\ln (\mathrm{HC})$ is -3.562350 , so that both series do not have a unit root problem at first differencing.

For China, the ADF value for the first difference in $\ln (\mathrm{yg})$ is -6.227533 and the ADF value for the first difference in $\ln (\mathrm{HC})$ is -4.115981 , so that both series do not have a unit root problem at first differencing.

For Costa Rica, the ADF value for the first difference in $\ln (\mathrm{yg})$ is -5.148734 and the ADF value for the first difference in $\ln (\mathrm{HC})$ is -3.593081 , so that both series do not have a unit root problem at first differencing.

For Ethiopia, the ADF value for the first difference in $\ln (\mathrm{yg})$ is -6.082653 and the ADF value for the first difference in $\ln (\mathrm{HC})$ is -3.858017 , so that both series do not have a unit root problem at first differencing.

For Gambia, the ADF value for the first difference in $\ln (\mathrm{yg})$ is -3.302050 and the ADF value for the first difference in $\ln (\mathrm{HC})$ is -3.689248 , so that both series do not have a unit root problem at first differencing.

For Iran, the ADF value for the first difference in $\ln (\mathrm{yg})$ is -5.273383 and the ADF value for the first difference in $\ln (\mathrm{HC})$ is -4.278055 , so that both series do not have a unit root problem at first differencing.

For Jamaica, the ADF value for the first difference in $\ln (\mathrm{yg})$ is -3.240918 and the ADF value for the first difference in $\ln (\mathrm{HC})$ is -4.730448 , so that both series do not have a unit root problem at first differencing.

For Kenya, the ADF value for the first difference in $\ln (\mathrm{yg})$ is -5.421356 and the ADF value for the first difference in $\ln (\mathrm{HC})$ is -3.289850 , so that both series do not have a unit root problem at first differencing.

For Mauritius, the ADF value for the first difference in $\ln (\mathrm{yg})$ is -6.383855 and the ADF value for the first difference in $\ln (\mathrm{HC})$ is -4.817244 , so that both series do not have a unit root problem at first differencing.

For South Africa, the ADF value for the first difference in $\ln (\mathrm{yg})$ is -3.789067 and the ADF value for the first 
difference in $\ln (\mathrm{HC})$ is -3.136529 , so that both series do not have a unit root problem at first differencing.

For Swaziland, the ADF value for the first difference in $\ln (\mathrm{yg})$ is -4.837577 and the ADF value for the first difference in $\ln (\mathrm{HC})$ is -3.961980 , so that both series do not have a unit root problem at first differencing.

For Thailand, the ADF value for the first difference in $\ln (\mathrm{yg})$ is -2.836 .18 and the ADF value for the first difference in $\ln (\mathrm{HC})$ is -3.505748 , so that both series do not have a unit root problem at first differencing.

For Tunisia, the ADF value for the first difference in $\ln (\mathrm{yg})$ is -5.423538 and the ADF value for the first difference in $\ln (\mathrm{HC})$ is -5.167146 , so that both series do not have a unit root problem at first differencing.

In sum, for all developing countries in this study, the problem of unit root is not present after first differencing.

Table 2. Unit Root Test for Developed Countries

\begin{tabular}{|c|c|c|c|c|c|c|c|}
\hline & \multicolumn{7}{|c|}{ Variable in } \\
\hline & & \multicolumn{3}{|c|}{ Level } & \multicolumn{3}{|c|}{ First Diff. } \\
\hline & & ADF Value & Decision & Sig. & ADF Value & Decision & Sig. \\
\hline \multirow[t]{3}{*}{1.} & Austria & & & & & & \\
\hline & $\ln (y g)$ & -4.818197 & No Unit Root & 0.01 & -4.989213 & No Unit Root & 0.01 \\
\hline & $\ln (\mathrm{HC})$ & -2.825080 & No Unit Root & 0.10 & -4.311724 & No Unit Root & 0.01 \\
\hline \multicolumn{8}{|c|}{ Canada } \\
\hline & $\ln (y g)$ & -1.791570 & Unit Root & N/A & -2.223554 & No Unit Root & 0.05 \\
\hline & $\ln (\mathrm{HC})$ & -1.286301 & Unit Root & $\mathrm{N} / \mathrm{A}$ & -3.081176 & No Unit Root & 0.05 \\
\hline \multicolumn{8}{|c|}{ Denmark } \\
\hline & $\ln (y g)$ & -2.338283 & Unit Root & N/A & -1.874041 & No Unit Root & 0.10 \\
\hline & $\ln (\mathrm{HC})$ & -3.794687 & No Unit Root & 0.01 & -6.006697 & No Unit Root & 0.01 \\
\hline \multicolumn{8}{|c|}{ Finland } \\
\hline & $\ln (y g)$ & -2.395779 & Unit Root & N/A & -2.905519 & No Unit Root & 0.10 \\
\hline & $\ln (\mathrm{HC})$ & -1.891617 & Unit Root & N/A & -2.698205 & No Unit Root & 0.10 \\
\hline \multicolumn{8}{|c|}{ France } \\
\hline & $\ln (\mathrm{yg})$ & -1.749180 & No Unit Root & 0.10 & -2.591358 & No Unit Root & 0.10 \\
\hline & $\ln (\mathrm{HC})$ & -1.286073 & Unit Root & N/A & -5.323739 & No Unit Root & 0.01 \\
\hline \multicolumn{8}{|c|}{ Ireland } \\
\hline & $\ln (y g)$ & -0.229007 & Unit Root & N/A & -2.967344 & No Unit Root & 0.01 \\
\hline & $\ln (\mathrm{HC})$ & -1.855852 & Unit Root & N/A & -3.590305 & No Unit Root & 0.05 \\
\hline \multicolumn{8}{|c|}{ Japan } \\
\hline & $\ln (y g)$ & -3.128069 & No Unit Root & 0.05 & -4.730489 & No Unit Root & 0.01 \\
\hline & $\ln (\mathrm{HC})$ & -1.578980 & Unit Root & $\mathrm{N} / \mathrm{A}$ & -3.546470 & No Unit Root & 0.05 \\
\hline \multicolumn{8}{|c|}{ Korea } \\
\hline & $\ln (y g)$ & -5.260741 & No Unit Root & 0.01 & -6.184739 & No Unit Root & 0.01 \\
\hline & $\ln (\mathrm{HC})$ & -2.889577 & Unit Root & N/A & -3.34128 & No Unit Root & 0.10 \\
\hline \multicolumn{8}{|c|}{ Netherlands } \\
\hline & $\ln (y g)$ & -3.415558 & No Unit Root & 0.05 & -4.238314 & No Unit Root & 0.01 \\
\hline & $\ln (\mathrm{HC})$ & -1.110990 & Unit Root & N/A & -2.810051 & No Unit Root & 0.10 \\
\hline \multicolumn{8}{|c|}{ New Zealand } \\
\hline & $\ln (y g)$ & -2.315105 & Unit Root & N/A & -3.929227 & No Unit Root & 0.05 \\
\hline & $\ln (\mathrm{HC})$ & -1.883917 & Unit Root & N/A & -3.853914 & No Unit Root & 0.05 \\
\hline \multicolumn{8}{|c|}{ Norway } \\
\hline & $\ln (y g)$ & -2.623761 & Unit Root & N/A & -2.979327 & No Unit Root & 0.10 \\
\hline & $\ln (\mathrm{HC})$ & -2.167523 & Unit Root & N/A & -4.188543 & No Unit Root & 0.01 \\
\hline \multicolumn{8}{|c|}{ Portugal } \\
\hline & $\ln (y g)$ & -1.246827 & Unit Root & N/A & -1.691874 & No Unit Root & 0.10 \\
\hline & $\ln (\mathrm{HC})$ & -2.005441 & Unit Root & N/A & -5.241003 & No Unit Root & 0.01 \\
\hline \multicolumn{8}{|c|}{ Switzerland } \\
\hline & $\ln (y g)$ & -1.774527 & No Unit Root & 0.10 & -2.825359 & No Unit Root & 0.01 \\
\hline & $\ln (\mathrm{HC})$ & -2.264527 & Unit Root & N/A & -3.348882 & No Unit Root & 0.05 \\
\hline \multicolumn{8}{|c|}{ United Kingdom } \\
\hline & $\ln (y g)$ & -1.777071 & Unit Root & $\mathrm{N} / \mathrm{A}$ & -2.062403 & No Unit Root & 0.10 \\
\hline & $\ln (\mathrm{HC})$ & -3.240669 & No Unit Root & 0.10 & -3.551885 & No Unit Root & 0.10 \\
\hline \multicolumn{8}{|c|}{ United States of Amer } \\
\hline & $\ln (y g)$ & -3.187641 & No Unit Root & 0.05 & -3.467734 & No Unit Root & 0.05 \\
\hline & $\ln (\mathrm{HC})$ & -2.268045 & Unit Root & N/A & -3.736790 & No Unit Root & 0.05 \\
\hline
\end{tabular}

Note: N/A Not Applicable 
According to table 2, for Austria, the ADF value for the first difference in $\ln (\mathrm{yg})$ is -4.989213 and the ADF value for the first difference in $\ln (\mathrm{HC})$ is -4.311724 , so that both series do not have a unit root problem at first differencing.

For Canada, the ADF value for the first difference in $\ln (\mathrm{yg})$ is -2.223554 and the ADF value for the first difference in $\ln (\mathrm{HC})$ is -3.081176 , so that both series do not have a unit root problem at first differencing.

For Denmark, the ADF value for the first difference in $\ln (\mathrm{yg})$ is -1.874041 and the ADF value for the first difference in $\ln (\mathrm{HC})$ is -6.006697 , so that both series do not have a unit root problem at first differencing.

For Finland, the ADF value for the first difference in $\ln (\mathrm{yg})$ is -2.905519 and the ADF value for the first difference in $\ln (\mathrm{HC})$ is -2.698205 , so that both series do not have a unit root problem at first differencing.

For France, the ADF value for the first difference in $\ln (\mathrm{yg})$ is -2.591358 and the ADF value for the first difference in $\ln (\mathrm{HC})$ is -5.323739 , so that both series do not have a unit root problem at first differencing.

For Ireland, the ADF value for the first difference in $\ln (\mathrm{yg})$ is -2.967344 and the ADF value for the first difference in $\ln (\mathrm{HC})$ is -3.590305 , so that both series do not have a unit root problem at first differencing.

For Japan, the ADF value for the first difference in $\ln (\mathrm{yg})$ is -4.730489 and the ADF value for the first difference in $\ln (\mathrm{HC})$ is -3.546470 , so that both series do not have a unit root problem at first differencing.

For Korea, the ADF value for the first difference in $\ln (\mathrm{yg})$ is -6.184739 and the ADF value for the first difference in $\ln (\mathrm{HC})$ is -3.34128 , so that both series do not have a unit root problem at first differencing.

For Netherlands, the ADF value for the first difference in $\ln (\mathrm{yg})$ is -4.238314 and the ADF value for the first difference in $\ln (\mathrm{HC})$ is -2.810051 , so that both series do not have a unit root problem at first differencing.

For New Zealand, the ADF value for the first difference in $\ln (\mathrm{yg})$ is -3.929227 and the ADF value for the first difference in $\ln (\mathrm{HC})$ is -3.853914 , so that both series do not have a unit root problem at first differencing.

For Norway, the ADF value for the first difference in $\ln (\mathrm{yg})$ is -2.979327 and the ADF value for the first difference in $\ln (\mathrm{HC})$ is -4.188543 , so that both series do not have a unit root problem at first differencing.

For Portugal, the ADF value for the first difference in $\ln (\mathrm{yg})$ is -1.691874 and the ADF value for the first difference in $\ln (\mathrm{HC})$ is -5.241003 , so that both series do not have a unit root problem at first differencing.

For Switzerland, the ADF value for the first difference in $\ln (\mathrm{yg})$ is -2.825359 and the ADF value for the first difference in $\ln (\mathrm{HC})$ is -3.348882 , so that both series do not have a unit root problem at first differencing.

For United Kingdom, the ADF value for the first difference in $\ln (\mathrm{yg})$ is -2.062403 and the ADF value for the first difference in $\ln (\mathrm{HC})$ is -3.551885 , so that both series do not have a unit root problem at first differencing.

For United States of America, the ADF value for the first difference in $\ln (\mathrm{yg})$ is -3.467734 and the ADF value for the first difference in $\ln (\mathrm{HC})$ is -3.736790 , so that both series do not have a unit root problem at first differencing.

In sum, for all developed countries in this study, the problem of unit root is not present after first differencing.

After having examined the unit root problem, the second step is to perform a diagnostic test necessary for time series data. We employ a standard test, Durbin-Watson test, to see if serial correlation or autocorrelation problem exists. The test results for developing countries and developed countries are shown in table 3 and 4, respectively.

Table 3. Diagmostic Test (Test for No Autocorrelation) for Developing Countries

\begin{tabular}{|c|c|c|c|c|}
\hline \multirow[b]{2}{*}{ Country } & \multicolumn{2}{|c|}{$y g=f(H C)$} & \multicolumn{2}{|c|}{$\mathrm{HC}=\mathrm{f}(\mathrm{yg})$} \\
\hline & D.W. stat & Result & D.W. stat & Result \\
\hline Argentina & 2.194870 & No Autocorrelation & 2.385432 & No Autocorrelation \\
\hline Bangladesh & 1.455508 & No Autocorrelation & 2.433005 & No Autocorrelation \\
\hline Cameroon & 1.879802 & No Autocorrelation & 2.151078 & No Autocorrelation \\
\hline China & 2.397953 & No Autocorrelation & 1.694041 & No Autocorrelation \\
\hline Costa Rica & 1.321602 & No Autocorrelation & 2.303190 & No Aotocorrelation \\
\hline Ethiopia & 1.666261 & No Autocorrelation & 2.375624 & No Autocorrelation \\
\hline Gambia & 2.575845 & No Autocorrelation & 2.446671 & No Autocorrelation \\
\hline Iran & 2.321783 & No Autocorrelation & 2.350146 & No Autocorrelation \\
\hline Jamaica & 2.139526 & No Autocorrelation & 2.803208 & Inconclusive \\
\hline
\end{tabular}




\begin{tabular}{lllll} 
10. Kenya & 1.443535 & No Autocorrealtion & 2.371305 & No Autocorrelation \\
11. Mauritius & 2.787285 & Inconclusive & 2.661625 & No Autocorrelation \\
12. South Africa & 1.353632 & No Autocorrelation & 2.278294 & No Autocorrelation \\
13. Swaziland & 2.469622 & No Autocorrelation & 2.414084 & No Autocorrelation \\
14. Thailand & 1.774356 & No Autocorrelation & 2.041997 & No Autocorrelation \\
15. Tunisia & 2.700770 & No Autocorrelation & 3.041258 & Autocorrelation \\
\hline
\end{tabular}

According to table 3, the results show that in most cases we find either no autocorrelation or inconclusion, which need not any corrections, whereas there is only one case for Tunisia that autocorreation is detected. Therefore, we correct for autocorrelation.

Table 4. Diagmostic Test (Test for No Autocorrelation) for Developed Countries

\begin{tabular}{lllcl}
\hline & \multicolumn{2}{c}{$\mathrm{yg}=\mathrm{f}(\mathrm{HC})$} & \multicolumn{2}{c}{$\mathrm{HC}=\mathrm{f}(\mathrm{yg})$} \\
\hline Country & D.W. stat & \multicolumn{1}{c}{ Result } & D.W. stat & Result \\
\hline 1. Autria & 1.530287 & No Autocorrelation & 2.326459 & No Autocorrelation \\
2. Canada & 2.344520 & No Autocorrelation & 2.367577 & No Autocorrelation \\
3. Denmark & 2.967961 & Inconclusive & 2.639585 & No Autocorrelation \\
4. Finland & 1.833945 & No Autocorrelation & 2.162097 & No Autocorrelation \\
5. France & 1.596582 & No Autocorrelation & 2.120584 & No Aotocorrelation \\
6. Ireland & 1.458767 & No Autocorrelation & 2.432204 & No Autocorrelation \\
7. Japan & 2.044590 & No Autocorrelation & 2.907495 & Inconclusive \\
8. Korea & 1.749135 & No Autocorrelation & 2.732422 & No Autocorrelation \\
9. Nethelands & 1.700801 & No Autocorrelation & 2.052892 & No Autocorrealtion \\
10. New Zealand & 1.841442 & No Autocorrealtion & 2.381338 & No Autocorrelation \\
11. Norway & 1.741655 & No Autocorrealtion & 1.921572 & No Autocorrelation \\
12. Portugal & 3.082408 & Autocorrelation & 2.311467 & No Autocorrelation \\
13. Switzerland & 1.630434 & No Autocorrelation & 2.580441 & No Autocorrelation \\
14. United Kingdom & 1.319295 & No Autocorrelation & 1.758973 & No Autocorrelation \\
15. United States & 2.350223 & No Autocorrelation & 2.510464 & No Autocorrelation \\
\hline
\end{tabular}

According to table 4, the results show that in most cases we find either no autocorrelation or inconclusion, which need not any correction, whereas there is only one case for Portugal that we find autocorreation which is corrected, accordingly.

The next step is to determine whether causal relationships exist. If so, which direction? Four possibilities are having the causation running from human capital to growth, having the causation running from growth to human capital, having reciprocal causation running from human capital to growth and from growth to human capital, and having neutrality. The neutrality means no empirical evidence of the causation for both variables. However, it is theoretically impossible to claim that the growth rate definitely leads to the human capital or vice versa, so the empirical evidence following Granger causality test is investigated. The specifications are as follows.

$$
\begin{aligned}
& \ln y g(t)=\gamma_{0}+\sum_{i=1}^{k+d} \alpha_{1 i} \ln y g(t-1)+\sum_{j=1}^{k+d} \beta_{1 j} \ln H C(t-1)+\varepsilon_{1}(t), \\
& \ln H C(t)=\delta_{0}+\sum_{i=1}^{k+d} \alpha_{2 i} \ln H C(t-1)+\sum_{j=1}^{k+d} \beta_{2 j} \ln y g(t-1)+\varepsilon_{2}(t),
\end{aligned}
$$

Then, with maximal order of integration $(\mathrm{dmax}=1)$ and optimal lag $(\mathrm{k}=1,2,3)$,

$$
\begin{aligned}
& \ln y g(t)=\gamma_{0}+\sum_{i=1}^{k+1} \alpha_{1 i} \ln y g(t-1)+\sum_{j=1}^{k+1} \beta_{1 j} \ln H C(t-1)+\varepsilon_{1}(t), \\
& \ln H C(t)=\delta_{0}+\sum_{i=1}^{k+1} \alpha_{2 i} \ln H C(t-1)+\sum_{j=1}^{k+1} \beta_{2 j} \ln y g(t-1)+\varepsilon_{2}(t),
\end{aligned}
$$

The Granger causality test results di $\overline{\mathrm{r} e}$ provided in table $5^{-1}$ and 6 . 
Table 5. Granger-causality Test for Developing Countries

Null Hypothesis Lag No. of Obs.

1. Argentina

$\begin{array}{cc}\text { Yg does not Granger } & 2 \\ \text { Cause HC } & 3 \\ & 4 \\ \text { HC does not Granger } & 2 \\ \text { Cause Yg } & 3 \\ & 4\end{array}$

2. Bangladesh

$\begin{array}{ccc}\text { Yg does not Granger } & 2 & 28 \\ \text { Cause HC } & 3 & 27 \\ \text { HC does not Granger } & 4 & 26 \\ \text { Cause Yg } & 3 & 27 \\ & 4 & 26\end{array}$

3. Cameroon

$\begin{array}{ccc}\text { Yg does not Granger } & 2 & 28 \\ \text { Cause HC } & 3 & 27 \\ \text { HC does not Granger } & 4 & 2 \\ \text { Cause Yg } & 3 & 28 \\ & 4 & 26\end{array}$

4. China

$\begin{array}{ccc}\text { Yg does not Granger } & 2 & 28 \\ \text { Cause HC } & 3 & 27 \\ \text { HC does not Granger } & 4 & 2 \\ \text { Cause Yg } & 3 & 28 \\ & 4 & 26\end{array}$

5. Costa Rica

$\begin{array}{ccc}\text { Yg does not Granger } & 2 & 28 \\ \text { Cause HC } & 3 & 27 \\ \text { HC does not Granger } & 4 & 26 \\ \text { Cause Yg } & 3 & 28 \\ & 4 & 27\end{array}$

6. Ethiopia

$\begin{array}{ccc}\text { Yg does not Granger } & 2 & 28 \\ \text { Cause HC } & 3 & 27 \\ & 4 & 26 \\ \text { HC does not Granger } & 2 & 28 \\ \text { Cause Yg } & 3 & 27 \\ & 4 & 26\end{array}$

7. Gambia

$\begin{array}{ccc}\text { Yg does not Granger } & 2 & 28 \\ \text { Cause HC } & 3 & 27 \\ \text { HC does not Granger } & 4 & 2 \\ \text { Cause Yg } & 2 & 28 \\ & 3 & 2 \\ & 4 & 2\end{array}$

8. Iran

$\begin{array}{ccc}\text { Yg does not Granger } & 2 & 28 \\ \text { Cause HC } & 3 & 27 \\ \text { HC does not Granger } & 4 & 2 \\ \text { Cause Yg } & 3 & 2 \\ & 4 & 2\end{array}$

\section{Jamaica}

$\begin{array}{cll}\text { Yg does not Granger } & 2 & 28 \\ \text { Cause HC } & 3 & 27\end{array}$

\begin{tabular}{lll} 
F-stat & Prob. & Decision \\
\hline 6.28314 & 0.00665 & Reject*** \\
3.72565 & 0.02814 & Reject** \\
4.46855 & 0.01192 & Reject** \\
2.05412 & 0.15108 & Accept \\
0.80856 & 0.50395 & Accept \\
0.21998 & 0.92358 & Accept
\end{tabular}

$\begin{array}{lll}0.73372 & 0.49103 & \text { Accept } \\ 0.72451 & 0.54920 & \text { Accept } \\ 1.02986 & 0.42031 & \text { Accept } \\ 3.56779 & 0.04472 & \text { Reject** } \\ 1.62488 & 0.21523 & \text { Accept } \\ 2.24177 & 0.10745 & \text { Accept }\end{array}$

$0.25929 \quad 0.77383 \quad$ Accept

0.33759

1.46830

0.19376

0.24450

0.27962

0.79833

0.25546

0.82518

0.86424

0.88710

Accept

Accept

Accept

Accept

Accept

Accept

$\begin{array}{lcc}0.98313 & 0.38932 & \text { Accept } \\ 0.92123 & 0.44855 & \text { Accept } \\ 0.56371 & 0.69224 & \text { Accept } \\ 0.31196 & 0.73506 & \text { Accept } \\ 0.26244 & 0.85160 & \text { Accept } \\ 0.33183 & 0.85272 & \text { Accept }\end{array}$

$3.09809 \quad 0.06436 \quad$ Reject*

$1.91915 \quad 0.15966 \quad$ Accept

$2.60526 \quad 0.07269 \quad$ Reject*

$0.11732 \quad 0.88983 \quad$ Accept

$0.84274 \quad 0.48652 \quad$ Accept

$0.69703 \quad 0.60442 \quad$ Accept

$0.03873 \quad 0.96207 \quad$ Accept

$0.15397 \quad 0.92590 \quad$ Accept

$0.08065 \quad 0.98724 \quad$ Accept

$6.12477 \quad 0.00737 \quad$ Reject***

$1.96272 \quad 0.15210 \quad$ Accept

$2.58693 \quad 0.07411 \quad$ Reject*

$0.13180 \quad 0.87777 \quad$ Accept

$0.02629 \quad 0.99378 \quad$ Accept

$0.18873 \quad 0.93238 \quad$ Accept

$0.85998 \quad 0.44768 \quad$ Accept

$3.04163 \quad 0.09259 \quad$ Reject*

$1.191284 \quad 0.27266 \quad$ Accept

$\begin{array}{lcl}0.88430 & 0.42658 & \text { Accept } \\ 2.04896 & 0.13934 & \text { Accept } \\ 1.45351 & 0.25980 & \text { Accept } \\ 1.00377 & 0.38199 & \text { Accept } \\ 2.73150 & 0.07091 & \text { Reject* } \\ 1.47798 & 0.25265 & \text { Accept } \\ & & \\ 0.54711 & 0.58596 & \text { Accept } \\ 0.42755 & 0.73544 & \text { Accept }\end{array}$




$\begin{array}{ccc} & 4 & 26 \\ \text { HC does not Granger } & 2 & 28 \\ \text { Cause Yg } & 3 & 27\end{array}$

10. Kenya

$\begin{array}{ccc}\text { Yg does not Granger } & 2 & 2 \\ \text { Cause HC } & 3 & 27 \\ \text { HC does not Granger } & 4 & 2 \\ \text { Cause Yg } & 3 & 28 \\ & 4 & 26\end{array}$

11. Mauritius

$\begin{array}{ccc}\text { Yg does not Granger } & 2 & 28 \\ \text { Cause HC } & 3 & 2 \\ \text { HC does not Granger } & 4 & 26 \\ \text { Cause Yg } & 3 & 2 \\ & 4 & 26\end{array}$

12. South Africa

$\begin{array}{ccc}\text { Yg does not Granger } & 2 & 28 \\ \text { Cause HC } & 3 & 27 \\ \text { HC does not Granger } & 2 & 2 \\ \text { Cause Yg } & 3 & 27 \\ & 4 & 26\end{array}$

13. Swaziland

$\begin{array}{ccc}\text { Yg does not Granger } & 2 & 28 \\ \text { Cause HC } & 3 & 27 \\ \text { HC does not Granger } & 4 & 2 \\ \text { Cause Yg } & 3 & 2 \\ & 4 & 2\end{array}$

14. Thailand

$\begin{array}{ccc}\text { Yg does not Granger } & 2 & 28 \\ \text { Cause HC } & 3 & 27 \\ \text { HC does not Granger } & 4 & 26 \\ \text { Cause Yg } & 3 & 27 \\ & 4 & 26\end{array}$

15. Tunisia

$\begin{array}{ccc}\text { Yg does not Granger } & 2 & 28 \\ \text { Cause HC } & 3 & 27 \\ \text { HC does not Granger } & 4 & 26 \\ \text { Cause Yg } & 3 & 2 \\ & 4 & 26\end{array}$

\begin{tabular}{|c|c|c|}
\hline 0.62735 & 0.64950 & Accept \\
\hline 2.01834 & 0.15574 & Accept \\
\hline 1.43535 & 0.26214 & Accept \\
\hline 2.16213 & 0.11724 & Accept \\
\hline 0.72675 & 0.49425 & Accept \\
\hline 0.46153 & 0.71226 & Accept \\
\hline 0.34371 & 0.84469 & Accept \\
\hline 0.46932 & 0.63129 & Accept \\
\hline 0.57900 & 0.63556 & Accept \\
\hline 0.44713 & 0.77303 & Accept \\
\hline 0.86786 & 0.43315 & Accept \\
\hline 0.64030 & 0.59796 & Accept \\
\hline 0.42214 & 0.79050 & Accept \\
\hline 1.16459 & 0.32978 & Accept \\
\hline 4.74015 & 0.01176 & Reject** \\
\hline 3.76859 & 0.02265 & Reject** \\
\hline 3.47776 & 0.04791 & Reject** \\
\hline 2.30947 & 0.10726 & Accept \\
\hline 2.62698 & 0.07104 & Reject* \\
\hline 0.23137 & 0.79527 & Accept \\
\hline 0.18391 & 0.90608 & Accept \\
\hline 0.19951 & 0.93516 & Accept \\
\hline 2.16091 & 0.13804 & Accept \\
\hline 1.90883 & 0.16069 & Accept \\
\hline 1.33012 & 0.22904 & Accept \\
\hline 0.24696 & 0.78322 & Accept \\
\hline 0.48533 & 0.69626 & Accept \\
\hline 0.34049 & 0.84687 & Accept \\
\hline 3.05960 & 0.06634 & Reject* \\
\hline 1.85703 & 0.16944 & Accept \\
\hline 1.40529 & 0.27447 & Accept \\
\hline 0.23035 & 0.79606 & Accept \\
\hline 0.23010 & 0.87433 & Accept \\
\hline 0.33278 & 0.85208 & Accept \\
\hline 0.08594 & 0.91803 & Accept \\
\hline 0.25326 & 0.85772 & Accept \\
\hline 1.92857 & 0.17574 & Accept \\
\hline 0.35962 & 0.70284 & Accept \\
\hline 1.07269 & 0.39235 & Accept \\
\hline 1.58202 & 0.24711 & Accept \\
\hline
\end{tabular}

\footnotetext{
Note: $* * * \quad$ Sig. at $1 \%$

** Sig. at 5\%

* Sig. at $10 \%$
}

According to the results shown in table 5, for Argentina the hypothesis that Yg does not Granger cause HC is rejected after 2, 3 and 4 lags. This means that the growth rate of GDP causes human capital. In this case, it indicates that as the economy grows after 2 years, it will induce a rise in the percentage of government spending on education to GDP. In other words, it takes about 2 years that the growth will affect such the spending. Conversely, the hypothesis that $\mathrm{HC}$ does not Granger cause Yg is accepted for all lags. This indicates that HC does not cause economic growth at every lags.

For Bangladesh the hypothesis that $\mathrm{Yg}$ does not Granger cause HC is accepted after at every lags. This means that the growth rate of GDP does not cause human capital. In this case, it indicates that as the economy grows after 2 years, it will not induce a rise in the percentage of government spending on education to GDP. Conversely, 
the hypothesis that $\mathrm{HC}$ does not Granger cause Yg is rejected at 2 lags but not 3 and 4 lags. This indicates that $\mathrm{HC}$ does cause economic growth at 2 lags.

For Cameroon the hypothesis that Yg does not Granger cause HC is accepted at every lags. This means that the growth rate of GDP does not cause human capital. In this case, it indicates that as the economy grows, it will not induce a rise in the percentage of government spending on education to GDP. Similarly, the hypothesis that HC does not Granger cause Yg is accepted at every lags. This indicates that HC does not cause economic growth.

For China the hypothesis that $\mathrm{Yg}$ does not Granger cause HC is accepted at every lags. This means that the growth rate of GDP does not cause human capital. In this case, it indicates that as the economy grows, it will not induce a rise in the percentage of government spending on education to GDP. Similarly, the hypothesis that HC does not Granger cause Yg is accepted at every lags. This indicates that $\mathrm{HC}$ does not cause economic growth.

For Costa Rica the hypothesis that Yg does not Granger cause HC is rejected after 2 and 4 lags but not at 3 lags. This means that the growth rate of GDP causes human capital. In this case, it indicates that as the economy grows after 2 years and 4 years, it will induce a rise in the percentage of government spending on education to GDP. In other words, it takes about 2 or 4 years that the growth will affect such the spending. Conversely, the hypothesis that $\mathrm{HC}$ does not Granger cause Yg is accepted for all lags. This indicates that $\mathrm{HC}$ does not cause economic growth at every lags.

For Ethiopia the hypothesis that $\mathrm{Yg}$ does not Granger cause HC is accepted at every lags. This means that the growth rate of GDP does not cause human capital. In this case, it indicates that as the economy grows, it will not induce a rise in the percentage of government spending on education to GDP. Conversely, the hypothesis that HC does not Granger cause Yg is rejected after 2 and 4 years but not 3 years. This indicates that HC does cause economic growth at 2 and 4 lags.

For Gambia the hypothesis that Yg does not Granger cause HC is accepted at every lags. This means that the growth rate of GDP does not cause human capital. In this case, it indicates that as the economy grows, it will not induce a rise in the percentage of government spending on education to GDP. Conversely, the hypothesis that HC does not Granger cause $\mathrm{Yg}$ is accepted after 2 and 4 years but rejected after 3 years. This indicates that HC does cause economic growth at 3 lags.

For Iran the hypothesis that Yg does not Granger cause HC is accepted at every lags. This means that the growth rate of GDP does not cause human capital. In this case, it indicates that as the economy grows, it will not induce a rise in the percentage of government spending on education to GDP. Conversely, the hypothesis that HC does not Granger cause $\mathrm{Yg}$ is accepted after 2 and 4 years but rejected after 3 years. This indicates that $\mathrm{HC}$ does cause economic growth at 3 lags.

For Jamaica the hypothesis that Yg does not Granger cause HC is accepted at every lags. This means that the growth rate of GDP does not cause human capital. In this case, it indicates that as the economy grows, it will not induce a rise in the percentage of government spending on education to GDP. Similarly, the hypothesis that HC does not Granger cause Yg is accepted at every lags. This indicates that $\mathrm{HC}$ does not cause economic growth.

For Kenya the hypothesis that Yg does not Granger cause HC is accepted at every lags. This means that the growth rate of GDP does not cause human capital. In this case, it indicates that as the economy grows, it will not induce a rise in the percentage of government spending on education to GDP. Similarly, the hypothesis that HC does not Granger cause Yg is accepted at every lags. This indicates that $\mathrm{HC}$ does not cause economic growth.

For Mauritius the hypothesis that Yg does not Granger cause HC is accepted at every lags. This means that the growth rate of GDP does not cause human capital. In this case, it indicates that as the economy grows, it will not induce a rise in the percentage of government spending on education to GDP. Conversely, the hypothesis that HC does not Granger cause $\mathrm{Yg}$ is accepted at 2 years but rejected at 3 and 4 years. This indicates that $\mathrm{HC}$ does cause economic growth at 3 and 4 lags. That is to say the higher share of spending on education to GDP, the higher economic growth rate is. Note that this keeps on occurring after 3 years.

For South Africa the hypothesis that Yg does not Granger cause HC is rejected after 2 and 4 lags but not at 3 lags. This means that the growth rate of GDP causes human capital. In this case, it indicates that as the economy grows after 2 years and 4 years, it will induce a rise in the percentage of government spending on education to GDP. In other words, it takes about 2 or 4 years that the growth will affect such the spending. Conversely, the hypothesis that $\mathrm{HC}$ does not Granger cause Yg is accepted for all lags. This indicates that $\mathrm{HC}$ does not cause economic growth at every lags.

For Swaziland the hypothesis that Yg does not Granger cause HC is accepted at every lags. This means that the growth rate of GDP does not cause human capital. In this case, it indicates that as the economy grows, it will not 
induce a rise in the percentage of government spending on education to GDP. Similarly, the hypothesis that HC does not Granger cause $\mathrm{Yg}$ is accepted at every lags. This indicates that $\mathrm{HC}$ does not cause economic growth.

For Thailand the hypothesis that Yg does not Granger cause HC is rejected after 2 lags but not at 3 and 4 lags. This means that the growth rate of GDP causes human capital at 2 lags. In this case, it indicates that as the economy grows after 2 years, it will induce a rise in the percentage of government spending on education to GDP In other words, it takes about 2 years that the growth will affect such the spending. Conversely, the hypothesis that $\mathrm{HC}$ does not Granger cause Yg is accepted for all lags. This indicates that HC does not cause economic growth at every lags.

For Tunisia the hypothesis that Yg does not Granger cause HC is accepted at every lags. This means that the growth rate of GDP does not cause human capital. In this case, it indicates that as the economy grows, it will not induce a rise in the percentage of government spending on education to GDP. Similarly, the hypothesis that HC does not Granger cause $\mathrm{Yg}$ is accepted at every lags. This indicates that $\mathrm{HC}$ does not cause economic growth

Table 6. Granger-causality Test for Developed Countries

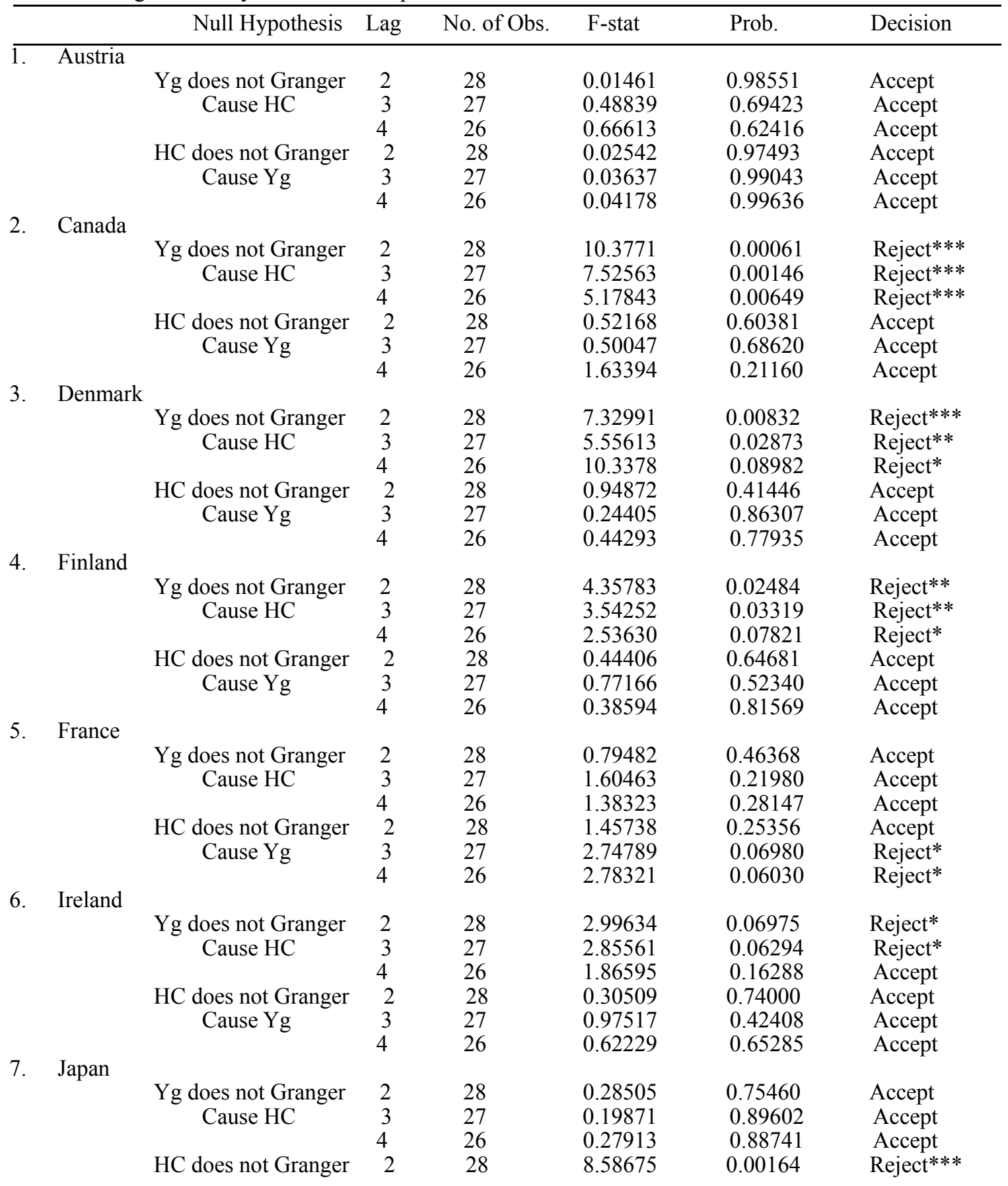


$\begin{array}{lll}\text { Cause Yg } & 3 & 27\end{array}$

8. Korea

Yg does not Granger 2

$\begin{array}{lll}\text { Cause HC } & 3 & 27\end{array}$

Yg does not Granger $\quad 2 \quad 28$

$\begin{array}{lll}\text { Cause HC } & 3 & 27\end{array}$

HC does not Granger $\quad 2 \quad 28$

Cause Yg

Cause HC

$4 \quad 26$

HC does not Granger Cause Yg

10. New Zealand

$\begin{array}{ccc}\text { Yg does not Granger } & 2 & 28 \\ \text { Cause HC } & 3 & 27 \\ & 4 & 26 \\ \text { HC does not Granger } & 2 & 28 \\ \text { Cause Yg } & 3 & 27 \\ & 4 & 26\end{array}$

11. Norway

$\begin{array}{ccc}\text { Yg does not Granger } & 2 & 28 \\ \text { Cause HC } & 3 & 27 \\ & 4 & 26 \\ \text { HC does not Granger } & 2 & 28 \\ \text { Cause Yg } & 3 & 27 \\ & 4 & 26\end{array}$

12. Portugal

Yg does not Granger
Cause HC

HC does not Granger Cause Yg

13. Switzerland

$\begin{array}{ccc}\text { Yg does not Granger } & 2 & 28 \\ \text { Cause HC } & 3 & 27 \\ & 4 & 26 \\ \text { HC does not Granger } & 2 & 28 \\ \text { Cause Yg } & 3 & 27 \\ & 4 & 26\end{array}$

14. United Kingdom

$\begin{array}{ccc}\text { Yg does not Granger } & 2 & 28 \\ \text { Cause HC } & 3 & 27 \\ \text { HC does not Granger } & 4 & 26 \\ \text { Cause Yg } & 3 & 27 \\ & 4 & 26\end{array}$

15. United States of America

$\begin{array}{cccccc}\text { Yg does not Granger } & 2 & 28 & 4.03617 & 0.03809 & \text { Reject** } \\ \text { Cause HC } & 3 & 27 & 1.86647 & 0.19369 & \text { Accept } \\ \text { HC does not Granger } & 4 & 26 & 3.56006 & 0.06877 & \text { Reject* } \\ \text { Cause Yg } & 3 & 28 & 0.00125 & 0.99875 & \text { Accept } \\ & 4 & 27 & 4.23249 & 0.03225 & \text { Reject** } \\ & 26 & 3.81479 & 0.05929 & \text { Reject* }\end{array}$

\footnotetext{
Note: $* * * \quad$ Sig. at $1 \%$

** Sig. at 5\%

* Sig. at $10 \%$

\begin{tabular}{|c|c|c|}
\hline 4.28230 & 0.01729 & Reject** \\
\hline 3.93105 & 0.01944 & Reject** \\
\hline 0.30301 & 0.74192 & Accept \\
\hline 1.42941 & 0.27106 & Accept \\
\hline 0.84317 & 0.52408 & Accept \\
\hline 1.66828 & 0.21376 & Accept \\
\hline 0.69702 & 0.56734 & Accept \\
\hline 0.74776 & 0.57803 & Accept \\
\hline 0.25723 & 0.77584 & Accept \\
\hline 0.16270 & 0.91990 & Accept \\
\hline 0.25780 & 0.89971 & Accept \\
\hline 0.17226 & 0.84306 & Accept \\
\hline 0.51602 & 0.68063 & Accept \\
\hline 0.40006 & 0.80520 & Accept \\
\hline 1.14560 & 0.34815 & Accept \\
\hline 0.39011 & 0.76348 & Accept \\
\hline 0.15183 & 0.95245 & Accept \\
\hline 1.07842 & 0.36870 & Accept \\
\hline 0.88034 & 0.49094 & Accept \\
\hline 1.74847 & 0.30081 & Accept \\
\hline 0.06434 & 0.93786 & Accept \\
\hline 0.79878 & 0.50904 & Accept \\
\hline 0.90314 & 0.48400 & Accept \\
\hline 1.14534 & 0.33560 & Accept \\
\hline 1.35181 & 0.28603 & Accept \\
\hline 5.32523 & 0.00575 & Reject*** \\
\hline 0.63587 & 0.54787 & Accept \\
\hline 2.37048 & 0.16952 & Accept \\
\hline 209.161 & 0.05181 & Reject* \\
\hline 1.10462 & 0.36545 & Accept \\
\hline 0.15003 & 0.92594 & Accept \\
\hline 12.1643 & 0.21143 & Accept \\
\hline 0.65755 & 0.52759 & Accept \\
\hline 0.44018 & 0.72678 & Accept \\
\hline 0.46661 & 0.75942 & Accept \\
\hline 5.51834 & 0.01103 & Reject** \\
\hline 3.53951 & 0.03328 & Reject** \\
\hline 2.58185 & 0.07452 & Reject* \\
\hline 6.57547 & 0.00551 & Reject*** \\
\hline 6.84845 & 0.00234 & Reject*** \\
\hline 6.39621 & 0.00588 & Reject*** \\
\hline 0.46853 & 0.63177 & Accept \\
\hline 0.51597 & 0.67600 & Accept \\
\hline 0.39621 & 0.80857 & Accept \\
\hline 4.03617 & 0.03809 & Reject** \\
\hline 1.86647 & 0.19369 & Accept \\
\hline 3.56006 & 0.06877 & Reject* \\
\hline 0.00125 & 0.99875 & Accept \\
\hline 4.23249 & 0.03225 & Reject** \\
\hline 3.81479 & 0.05929 & Reject* \\
\hline
\end{tabular}

4.28230
3.93105

0.30301

Accept

Accep

Accept

26

27

28

27

26

28

27

26

27

26

28

27

28

27
26

28

27

26

28

27

26

28 
According to the results shown in table 6, for Austria the hypothesis that Yg does not Granger cause HC is accepted at every lags. This means that the growth rate of GDP does not cause human capital. In this case, it indicates that as the economy grows, it will not induce a rise in the percentage of government spending on education to GDP. Similarly, the hypothesis that HC does not Granger cause Yg is accepted at every lags. This indicates that $\mathrm{HC}$ does not cause economic growth.

For Canada the hypothesis that Yg does not Granger cause $\mathrm{HC}$ is rejected after 2, 3 and 4 lags. This means that the growth rate of GDP causes human capital. In this case, it indicates that as the economy grows after 2 years, it will induce a rise in the percentage of government spending on education to GDP. In other words, it takes about 2 years that the growth will affect such the spending. Conversely, the hypothesis that HC does not Granger cause $\mathrm{Yg}$ is accepted for all lags. This indicates that $\mathrm{HC}$ does not cause economic growth at every lags.

For Denmark the hypothesis that Yg does not Granger cause HC is rejected after 2, 3 and 4 lags. This means that the growth rate of GDP causes human capital. In this case, it indicates that as the economy grows after 2 years, it will induce a rise in the percentage of government spending on education to GDP. In other words, it takes about 2 years that the growth will affect such the spending. Conversely, the hypothesis that HC does not Granger cause $\mathrm{Yg}$ is accepted for all lags. This indicates that HC does not cause economic growth at every lags.

For Finland the hypothesis that Yg does not Granger cause HC is rejected after 2, 3 and 4 lags. This means that the growth rate of GDP causes human capital. In this case, it indicates that as the economy grows after 2 years, it will induce a rise in the percentage of government spending on education to GDP. In other words, it takes about 2 years that the growth will affect such the spending. Conversely, the hypothesis that $\mathrm{HC}$ does not Granger cause $\mathrm{Yg}$ is accepted for all lags. This indicates that $\mathrm{HC}$ does not cause economic growth at every lags.

For France the hypothesis that Yg does not Granger cause HC is accepted at every lags. This means that the growth rate of GDP does not cause human capital. In this case, it indicates that as the economy grows, it will not induce a rise in the percentage of government spending on education to GDP. Conversely, the hypothesis that HC does not Granger cause Yg is accepted after 2 years but rejected after 3 and 4 years. This indicates that $\mathrm{HC}$ does cause economic growth at 3 and 4 lags. That is to say the higher share of spending on education to GDP, the higher economic growth rate is. Note that this keeps on occurring after 3 years.

For Ireland the hypothesis that Yg does not Granger cause HC is rejected at 2 and 3 lags but not 4 lags. This means that the growth rate of GDP causes human capital. In this case, it indicates that as the economy grows after 2 to 3 years, it will induce a rise in the percentage of government spending on education to GDP. In other words, it takes about 2 to 3 years that the growth will affect such the spending. Conversely, the hypothesis that $\mathrm{HC}$ does not Granger cause $\mathrm{Yg}$ is accepted for all lags. This indicates that $\mathrm{HC}$ does not cause economic growth at every lags.

For Japan the hypothesis that Yg does not Granger cause HC is accepted at every lags. This means that the growth rate of GDP does not cause human capital. In this case, it indicates that as the economy grows, it will not induce a rise in the percentage of government spending on education to GDP. Conversely, the hypothesis that HC does not Granger cause Yg is rejected after 2, 3 and 4 years. This indicates that $\mathrm{HC}$ does cause economic growth at 2, 3 and 4 lags. That is to say the higher share of spending on education to GDP, the higher economic growth rate is. Note that this keeps on occurring after 2 years.

For Korea the hypothesis that Yg does not Granger cause HC is accepted at every lags. This means that the growth rate of GDP does not cause human capital. In this case, it indicates that as the economy grows, it will not induce a rise in the percentage of government spending on education to GDP. Similarly, the hypothesis that HC does not Granger cause $\mathrm{Yg}$ is accepted at every lags. This indicates that $\mathrm{HC}$ does not cause economic growth.

For Netherlands the hypothesis that Yg does not Granger cause HC is accepted at every lags. This means that the growth rate of GDP does not cause human capital. In this case, it indicates that as the economy grows, it will not induce a rise in the percentage of government spending on education to GDP. Similarly, the hypothesis that HC does not Granger cause $\mathrm{Yg}$ is accepted at every lags. This indicates that $\mathrm{HC}$ does not cause economic growth.

For New Zealand the hypothesis that Yg does not Granger cause HC is accepted at every lags. This means that the growth rate of GDP does not cause human capital. In this case, it indicates that as the economy grows, it will not induce a rise in the percentage of government spending on education to GDP. Similarly, the hypothesis that $\mathrm{HC}$ does not Granger cause Yg is accepted at every lags. This indicates that $\mathrm{HC}$ does not cause economic growth.

For Norway the hypothesis that $\mathrm{Yg}$ does not Granger cause $\mathrm{HC}$ is accepted at every lags. This means that the growth rate of GDP does not cause human capital. In this case, it indicates that as the economy grows, it will not 
induce a rise in the percentage of government spending on education to GDP. However, the hypothesis that HC does not Granger cause Yg is accepted at 2 and 3 lags but rejected at 4 lags. This indicates that HC does cause economic growth at 4 lags.

For Portugal the hypothesis that Yg does not Granger cause HC is accpetd at 2 and 3 lags but not 4 lags. In other words, the growth rate of GDP causes human capital at 4 lags. In this case, it indicates that as the economy grows after 4 years, it will induce a rise in the percentage of government spending on education to GDP. That is, it takes about 4 years that the growth will affect such the spending. Conversely, the hypothesis that HC does not Granger cause $\mathrm{Yg}$ is accepted for all lags. This indicates that $\mathrm{HC}$ does not cause economic growth at every lags.

For Switzerland the hypothesis that Yg does not Granger cause HC is accepted at every lags. This means that the growth rate of GDP does not cause human capital. In this case, it indicates that as the economy grows, it will not induce a rise in the percentage of government spending on education to GDP. Conversely, the hypothesis that HC does not Granger cause Yg is rejected after 2, 3 and 4 years. This indicates that $\mathrm{HC}$ does cause economic growth at 2, 3 and 4 lags. That is to say the higher share of spending on education to GDP, the higher economic growth rate is. Note that this keeps on occurring after 2 years.

For United Kingdom the hypothesis that Yg does not Granger cause HC is rejected at 2, 3 and 4 lags. This means that the growth rate of GDP causes human capital. In this case, it indicates that as the economy grows after 2 years, it will induce a rise in the percentage of government spending on education to GDP. In other words, it takes about 2 years that the growth will affect such the spending. Conversely, the hypothesis that HC does not Granger cause $\mathrm{Yg}$ is accepted for all lags. This indicates that $\mathrm{HC}$ does not cause economic growth at every lags.

For United States of America the hypothesis that Yg does not Granger cause HC is rejected at 2 and 4 lags but 3 lags. This means that the growth rate of GDP causes human capital. In this case, it indicates that as the economy grows after 2 and 4 years, it will induce a rise in the percentage of government spending on education to GDP. In other words, it takes about 2 and 4 years that the growth will affect such the spending. Conversely, the hypothesis that $\mathrm{HC}$ does not Granger cause $\mathrm{Yg}$ is accepted at 2 lags but rejected at 3 and 4 lags. This indicates that $\mathrm{HC}$ does cause economic growth after 3 years. In sum, unlike others, for this country we see the bidirectional causation running from growth to human capital and from human capital to growth. This implies that as the economy grows, the share of education from the government sector will rise and afterwards when education human capital increases, the growth will increase as well.

Investigation of the relationship between human capital-growth and economic development level

According to the previous section results, we can summarize the outcome as table 7.

Table 7. Summary of Relationship Direction of Developing and Developed Countries

\begin{tabular}{llc}
\hline & \multicolumn{1}{c}{ Direction } & Number of Countries \\
\hline \multirow{5}{*}{ Developing Countries } & Causation: Growth -> HC & 4 \\
& Neutrality: Growth -> HC & 11 \\
& Causation: HC -> Growth & 5 \\
& Neutrality: HC -> Growth & 10 \\
\hline \multirow{5}{*}{ Developed Countries } & Causation: Growth -> HC & 7 \\
& Neutrality: Growth -> HC & 8 \\
& Causation: HC $->$ Growth & 5 \\
& Neutrality: HC -> Growth & 10 \\
\hline
\end{tabular}

According to the summarized results from table 7, for developing countries we see the neutrality more often than the causation. This is similar for developed countries. The neutrality: growth to human capital, for example, means that growth can explain growth itself better than both growth and human capital together can explain growth. However, we see the number of causations both running from growth to human capital and human capital to growth almost equally for developing countries. For developed countries, we see the number of causations running from growth to human capital more than that from human capital to growth even if those numbers are not much different.

Graphically, the relationship pattern between education human capital - economic growth and the level of economic development can be shown in figure 1 below. 
Level of Economic Development

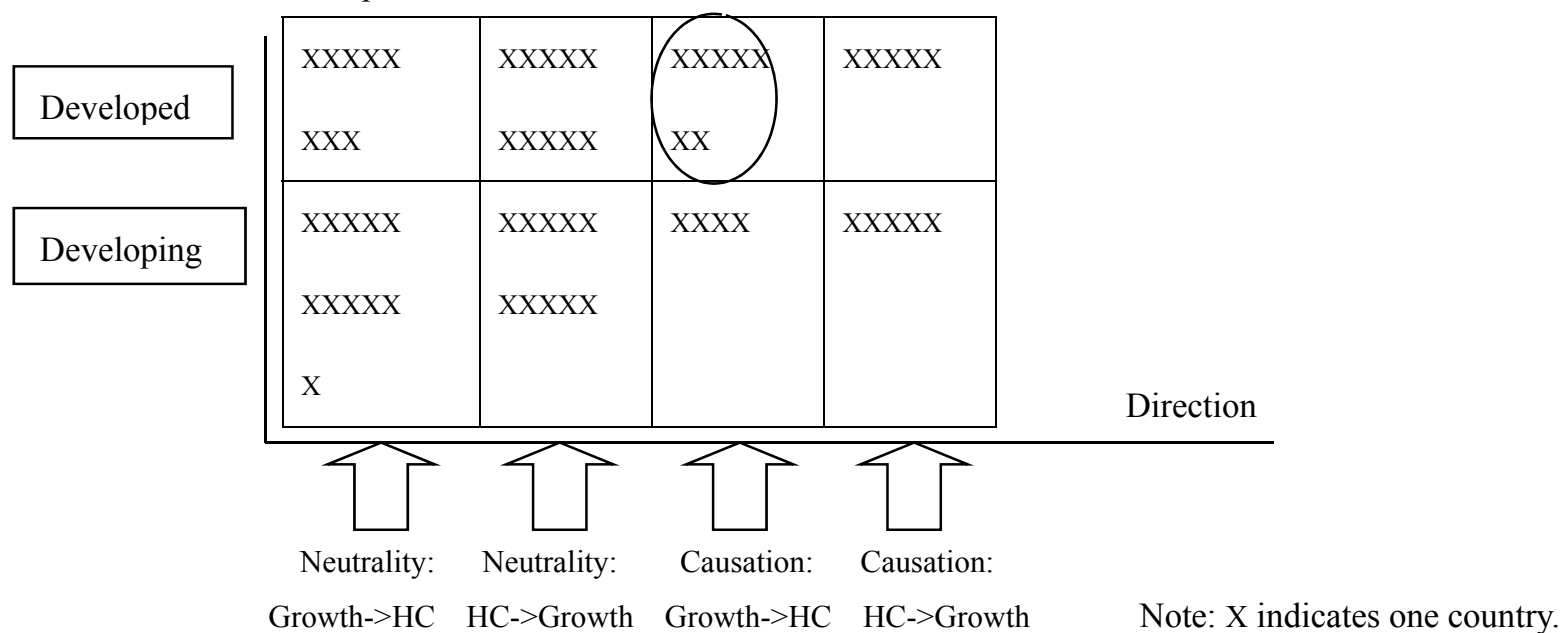

Figure 1. Relationship Pattern between Education Human Capital - Growth and Economic Development

From figure 1, we can see that both developing and developed countries have the neutrality direction the most compared to the causation either running from growth to human capital or from human capital to growth. Therefore, we can say that we see similar relation pattern for neutrality both from developing and developed countries. Nonetheless, we can see that for causation running from growth to human capital, the number of developed countries is almost double when compared with the developing countries $(7$ countries for the developed and 4 countries for the developing).

\section{Conclusion}

Human Capital has been identified as an indispensable factor of production and it becomes increasingly significant in terms of knowledge and capabilities embedded in labor either innate or later acquired throughout one's lifetime. The definition of human capital used in this study is solely education. More specifically, it is the government spending share on education.

This study has two aims; 1) to test the causal relationship between education human capital and economic growth using cross-country data and 2) to investigate the relationship pattern between human capital - growth and the level of economic development using cross-country data as well. The former is based on 30 country data which is separated to 15 developing countries and 15 developed countries, annually gathered during 1983-2012 periods. The latter is based on the empirical results from the former. For the causal relationship, the standard approach, unit root test and Granger Causality test has been performed. For the relationship pattern, frequency and graph are employed to respond to this query.

The results are as follows. In this study, every country both developing and developed countries has no unit root problem either at level or at first differencing. For the causal relationships, we see similar structure for both developing and developed countries. That is, the majority has neutrality direction, for both growth to human capital and human capital to growth, which means the variable of interest can explain itself better than the joint explanation with the other variable. And both developing and developed countries have unidirectional causation either growth to human capital and human capital to growth, except the United States of America, that we see the bidirectional causation. However, for the relationship pattern we see some evidence that developed countries tend to have the causation running from growth to human capital more than that of the developing ones.

The implication is that higher income countries are able to spend more money on education. Therefore, the human capital in terms of education tends to be higher than that of the developing countries. In other words, the more developed might consider spend more portion of their GDP on education since doing so will boost the human capital and in the long run, it will augment the economic growth through its spillover effect.

\section{Acknowledgments}

The author would like to thank the Department of Economics, Kasetsart University for the research grant and supports.

\section{References}

Arrow, K. J. (1962). The Economic Implications of Learning-by-Doing. Review of Economic Studies, 29(1), 
155-173. https://doi.org/10.2307/2295952.

Barro, R. J. (1991). Economic Growth in a Cross Section of Countries. The Quarterly Journal of Economics, 106(2), 407-419. https://doi.org/10.2307/2937943.

Becker, G. (1962). Investment in Human Capital: A Theoretical Analysis. Journal of Political Economy, 70, 9-49. Retrieved from http://www.jstor.org/stable/1829103.

Becker, G., \& Chiswick, B. R. (1966). Education and the Distribution of Earnings. American Economic Review, $56,358-369$.

Ben Porath, Y. (1967). The Production of Human Capital and the Life Cycle of Earnings. Journal of Political Economy, 75(4), 352-365. https://doi.org/10.1086/259291.

Ben Porath, Y. (1970). The Production of Human Capital Over Time. Education, Income, and Human Capital, National Bureau of Economic Research, New York. Retrieved from http://www.nber.org/chapters/c3278

Chandra, A. (2010). Does Government Expenditures on Education Promote Economic Growth? An Econometric Analysis. Central University Working Paper. Retrieved from https://mpra.ub.uni-muenchen.de/25480/1/MPRA

Haley, W. J. (1973). Human Capital: The Choice between Investment and Income. American Economic Review, 63, 929-944.

Haley, W. J. (1976) Estimation of the Earnings Profile from Optimal Human Capital Accumulation. Econometrica, 44(6), 1223-1238. https://doi.org/10.2307/1914256.

Heckman, J. J., Lochner, L. J., \& Petra, T. E. (2008). Earnings Functions and Rates of Return. Discussion Paper Series No. 3310, IZA. https://doi.org/10.3386/w11544.

Herrnstein, R. J., \& Murray, C. (1994). The Bell Curve: Intelligence and Class Structure in American Life. New York: The Free Press.

Imran, M. et al. (2012). Relationship between Human Capital and Economic Growth: Use of Co-integration Approach. Journal of Agriculture and Social Sciences, 8(4), 135-138.

Johnson, T. (1970). Returns to Investment in Human Capital. American Economic Review, 60, 546-560.

Johnson, T. (1978). Time in School: The Case of the Prudent Patron. American Economic Review, 68(5), $862-872$.

Mincer, J. J. (1962). Human Capital and Growth. American Economic Review, 91(2), 12-17.

Mincer, J. J. (1997). The Production of Human Capital and the Life Cycle of Earnings: Variations on a Theme. Journal of Labor Economics, 15(1), S26-S47. https://doi.org/10.1086/209855.

Mincer, J. (1970). Comments in the Production of Human Capital Over Time in Education, Income, and Human Capital. New York: National Bureau of Economic Research.

Monks, J. (1998). The Effect of Uncertain Returns on Human Capital Investment Patterns. American Economic Journal, 26(4), 413-418. https://doi.org/10.1007/bf02299453.

Neisser, et al. (1995). Intelligence: Knowns and Unknowns, Board of Scientific Affairs of the American Psychological Association.

Polachek, S. W. (1975). Differentials in Expected Post-Schooling Investment as a Determinant of Market Wage Differentials. International Economic Review, 16(2), 451-457. https://doi.org/10.2307/2525825.

Polachek, S. W., \& Siebert, W. S. (1993). The Economics of Earnings. New York: Cambridge University Press. https://doi.org/10.1017/cbo9780511522062.004.

Polachek, S. W. (2008). Earnings over the Lifecycle: The Mincer Earnings Function and Its Applications. Foundations and Trends in Microeconomics, 4(3).

Polachek, S. W., Das, T., \& Thamma-Apiroam, R. (2013). Heterogeneity in the Production of Human Capital. IZA Discussion Paper No. 7335.

Polachek, S. W., Das, T., \& Thamma-Apiroam, R. (2015). Micro- and Macroeconomic Implications of Heterogeneity in the Production of Human Capital. Journal of Political Economy, 6(123), 1410-1455. https://doi.org/10.1086/683989.

Romer, P. M. (1986). Increasing Returns and Long-Run Growth. Journal of Political Economy, 96(October 
1986), 1002-1037. https://doi.org/10.1086/261420.

Schultz, T. W. (1961). Investment in Human Capital. American Economic Review, 51(1), 1-17.

Thamma-Apiroam, R. (2015). Approaches for Human Capital Measurement with an Empirical Application for Growth Policy. Asian Social Science, 11(26), 309-322. https://doi.org/10.5539/ass.v11n26p309.

Uzawa, H. (1965). Optimal Technical Change in an Aggregate Model of EconomicGrowth. International Economic Review, 6, 18-31. https://doi.org/10.2307/2525621.

Wallace, T. D., \& Ihnen, L. A. (1975). Full-Time Schooling in Life-Cycle Models of Human Capital Accumulation. Journal of Political Economy, 83(1), 137-156. https://doi.org/10.1086/260310.

Wechsler, D. (1949). Manual for the Wechsler Intelligence Scale for Children. The Psychological Corporation, New York.

Weisbrod, B. A. (1972). Comment in Investment in Education: The Equity-Efficiency Quandary. Journal of Political Economy, 80(3), Part 2, S139-S141.

Wu, H. (2007). Can the Human Capital Approach Explain Life-Cycle Wage Differentials between Races and Sexes? Economic Inquiry, 45(1), 24-39. https://doi.org/10.1111/j.1465-7295.2006.00002.x.

Yildirim N., Deniz H., \& Hepsag A. (2011). Do Public Education Really Lead to Economic Growth? Evidence from Turkey. International Research Journal of Finance and Economics, 65, 12-24.

\section{Copyrights}

Copyright for this article is retained by the author(s), with first publication rights granted to the journal.

This is an open-access article distributed under the terms and conditions of the Creative Commons Attribution license (http://creativecommons.org/licenses/by/4.0/). 